\title{
Estimation of Energy Prices in Turkey in the Nash-Cournot Framework
}

\author{
Prof. Dr. Rengin Ak ${ }^{1}$
}

Assist. Prof. Dr. Armağan Türk ${ }^{2}$

Assoc. Prof. Dr. Hasan İslatince ${ }^{3}$

\section{Abstract}

Increase of mass production with the industrial revolution has increased the country's dependence on energy. Even today, energy constitutes the main weight of industrialization. Especially for countries dependent on energy from abroad, energy prices are very important, and fluctuations in energy prices are decisive for the economies of these countries. Fluctuations in energy prices make the future course of energy prices important for both energy demanding countries and energy-supplying countries. There are many methods in the related literature. Our estimate of energy prices for Turkey will be based on the NashCournot framework.

In the Nash-Cournot framework, energy is considered as a homogeneous commodity and market equilibrium is determined by the capacity-setting decisions of the suppliers. The model indicates that competitors aim to produce more by reacting to higher prices. A fundamental offer-based stochastic model is being put forward in order to predict the energy prices and the mean price in a given period. Two ambiguous sources are addressed, these are energy producers and demand. Studies have shown that the expected number of prices increases significantly with the decrease in the number of firms in the market. Within this framework, factors determining the energy prices in Turkey will be determined and forecasts for the future will be made.

\section{Keywords: Nash-Cournot, Energy Prices, Turkey.}

\section{INTRODUCTION}

The energy has become one of the indispensable sources for the countries in all periods of history. The energy being produced in large quantities was an important factor also in the transition from the production for residential demands to the mass production. The energy has become the main input and driving force of the industry upon the industrialization process. The intensive use of energy in every sector has increased the output together with improving the living standards. The energy demand of the industrial cities and the metropolitan cities, which have emerged along with the industrialization process, have rapidly increased. The great increase in the energy demand which has started in the 20th century has still been important in the 21 st century (Chart 1). The energy consumption also increases along with the industrialization and increasing population. The energy prices have become important for many countries as well as the production of energy in this framework.

\section{Chart 1: World Energy Consumption (1820-2010)}

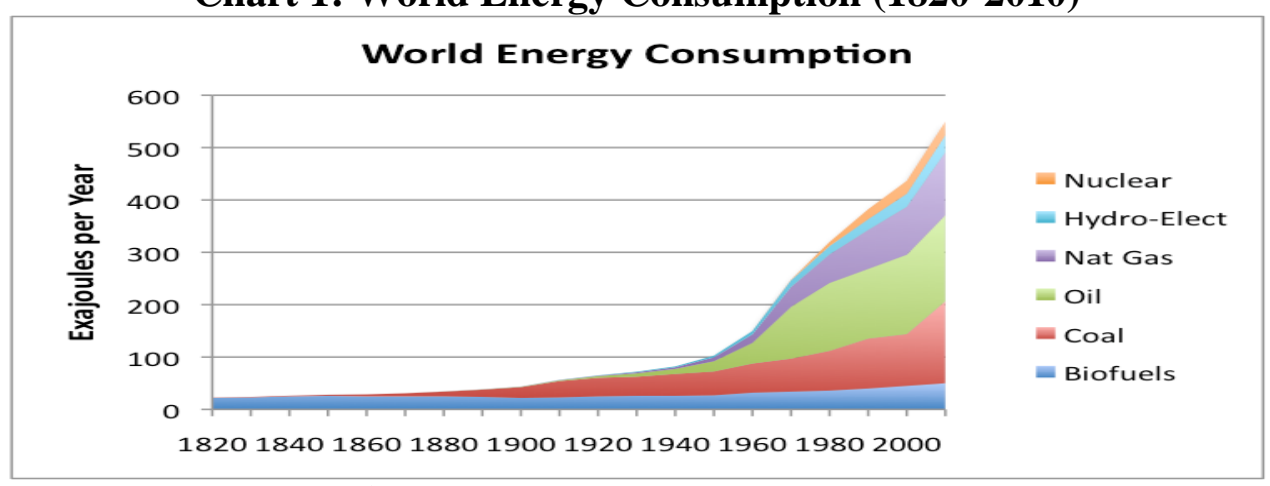

Source: Vlachogianni and Valavanidiss, 2013, 74 
The forecasting of the electricity prices as well as forecasting the future increases in the electricity demand is important. The actors in the market rely on the forecasts of energy prices to develop and decide on strategies for purchasing and selling electricity. The spot pricing requires determining real-time energy prices. Accurate forecasting of energy prices is necessary for institutions to be involved in the process.

The energy market has grown considerably in terms of the companies that generate, transmit, and distribute power over the years. Such developments are called vertically integrated structures. The vertical integration of public services makes it difficult to separate the generation, transmission, or distribution costs. Therefore, the companies that provide this service charge an average tariff rate to their service users based on their total costs over a period of time. In most cases, the price corrections are made by an external regulatory agency and the price corrections are based on non-economic reasons. The energy production industry is clearly stayed out of the energy transmission industry. The energy trade has become a very important part of the energy industry.

The number of companies in the energy sector in Turkey is 289 as of 2016.267 of these companies actually produce energy. However, the number of companies traded in the Istanbul Stock Exchange is very low. 5 energy and 3 electricity companies are traded in the Istanbul Stock Exchange. The number of energy companies traded in NASDAQ in the US is 319. Considering the general situation in the world, it is seen that the majority of the energy companies are among the biggest companies. The following table shows the largest energy companies in terms of earnings.

Table: 1 Energy Companies (Billion \$)

\begin{tabular}{|l|r|r|l|r|r|}
\hline Company & Origin & Income & Company & Origin & Income \\
\hline Endesa SA & Spain & 34,3 & Petro China Corp & China & 220,1 \\
\hline Rosneft Oil & Russia & 39,4 & E.On AG & Germany & 115,7 \\
\hline Reliance Industries & India & 43,6 & Total SA & France & 157,6 \\
\hline RWG AG & Germany & 65,2 & Petrobras Brasileiro & Brasil & 100,8 \\
\hline Lukoil & Russia & 104,9 & Gazprom & Russia & 98,1 \\
\hline Royal Dutch Shell & Holland & 278,1 & BP & England & 239,2 \\
\hline & & & Exxon Mobile & & \\
Chevron Corp & USA & 159,2 & Corp & USA & 275,5 \\
\hline China Petroleum & China & 192,6 & & & \\
\hline
\end{tabular}

Source: Business Insider, 2016

The accurate forecasting of the market prices is important for companies in the energy market to make a good decision. The companies make bilateral contracts to purchase or sell energy by accurately forecasting shortterm market prices Thus they get higher returns. The good forecasts of spot prices help establish profitable bilateral agreements. The prices can change hourly based on the impact of many external factors. Therefore, the actors in the market, both in terms of the company and the country, need a good forecasting toolbox to estimate the prices. In general, the price forecast also includes estimates of futures and forward market prices.

\section{Energy Prices And Forecasting Methods}

Forecasting of energy prices has become even more important after the regulation of energy markets globally. Many methods have been developed for forecasting the energy prices in the academic environment as well as in the agencies in the sector after 1980. Especially short-term estimation of the unstorable electricity energy has become important. This situation poses a high risk to market participants. Other factors having an impact on energy prices, except for not storability of the energy and the supply-demand imbalances, are shown in Figure 1.

In general, there are two possible methods of estimating electricity prices. The first approach is based on the simulation of the physical model of power grids and the numerical algorithms that consider the physical properties of power grids are applied. The simulation method requires numerous real-time knowledge about energy systems 
and it includes a complicated calculation. The second method is based on artificial intelligence, which maps between several input parameters and hourly market prices. The artificial intelligence models can be calculated simply and efficiently. However, it requires detailed and accurate input data for adaptation and forecasting together with appropriate artificial intelligence model (Daneshi and Daneshi, 2008: 2).

\section{Figure 1: Factors affecting the energy prices}

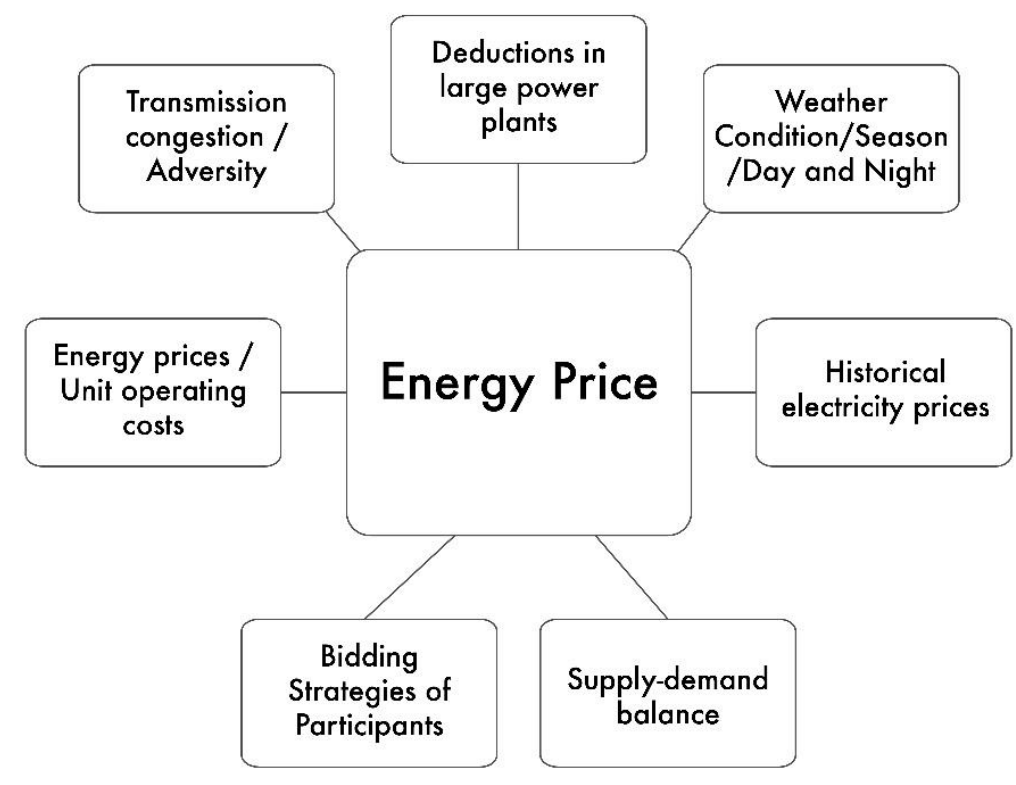

Source: Hu et.al., 2009:2.

Considering the classification of the price forecasting in the energy markets, short-term, medium-term, and long-term price forecasts are made. Although the terms are usually measured in years, the medium-term is used as monthly periods. The short-term may be for daily or hourly periods. The energy price forecasts vary based on the period. Time series, artificial intelligence, and hybrid models are generally preferred for short-term forecasts. The simulation, equilibrium (or game theory), production cost, and basic methods are preferred for the medium and longterm price forecasts. The models based on production cost try to simulate the operations of production units aiming to meet the demand for the minimum cost. Equilibrium (or game theory) approach uses processes based on equilibrium models for the market while forecasting energy prices. The basic methods define the price dynamics by modeling the effects of the major variables, which affect the energy prices, on the price. The simulation models create various scenarios in the future and they calculate the probability of the future price scenarios based on the risk assumptions (Cerjan et al., 2013: 756). The methods used for forecasting energy prices are classified in various ways in the literature. The energy prices forecasting is considered in terms of the preferred method for the forecasting in Chart 2. 


\section{Chart 2: Classification of the Price Forecasting Methods}

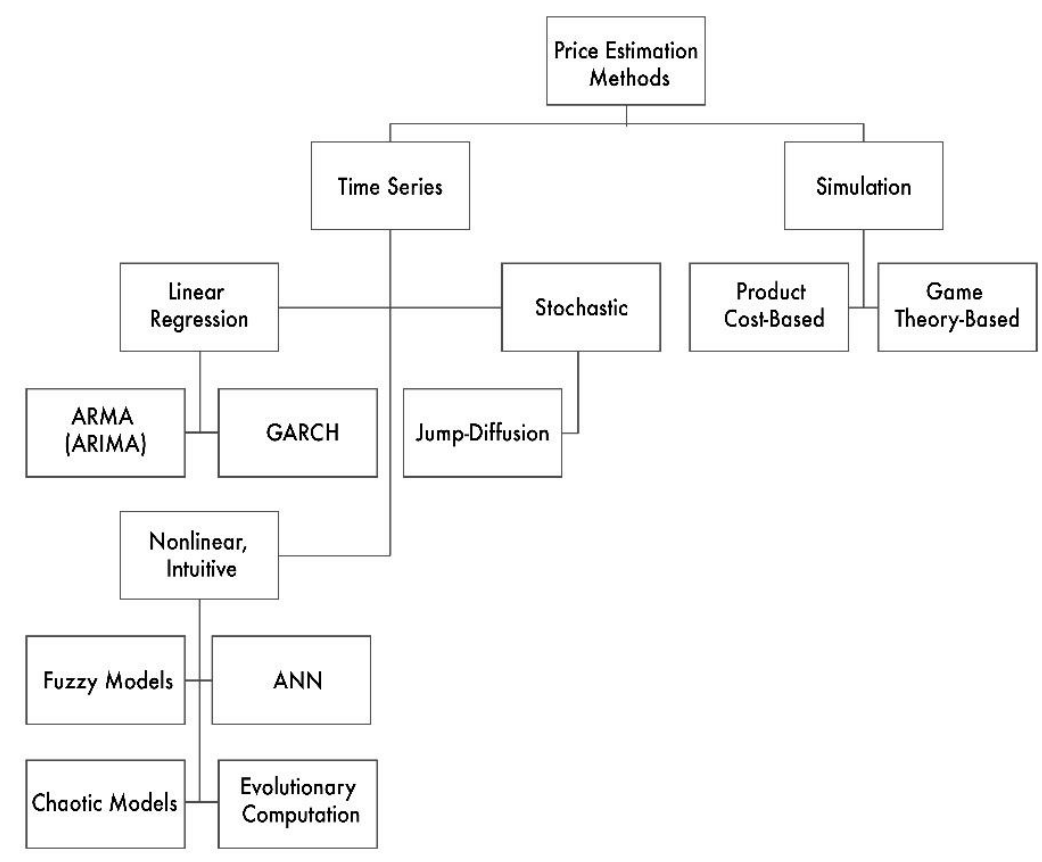

Source: Nimura, 2006:52.

Time series models can be seen in several different ways. The Static models such as ARIMA (Autoregressive Integrated Moving Average), non-static time series such as GARCH (Generalized Auto Regressive Conditional Heteroskedasticity), and DR (Dynamic Regression) can be expressed as examples of these models. These models have usually been used for short-term energy price forecasting in the literature.

Although most of the time series are linear predictors, most of the energy input prices are non-linear functions. Some studies have proposed using Neural Networks and Fuzzy Neural Networks to solve this problem (Cerjan et.al., 2013:757).

However, the energy price is a time change signal and the functional relationship changes over time. Thus, derived information or inferences of neural networks and fuzzy neural networks can reduce the value of the obtained result.

The hybrid methods combine both linear and nonlinear modeling features. In order to make the forecasts more effective and efficient, each model's specific characteristics are used to see the differences in the data. Nevertheless, there is no certain answer to the question of which of the above-mentioned models is the best. Table 2 shows the studies and methods used to forecast energy prices.

Table 2: The Literature on Energy Price Forecasting

\begin{tabular}{|l|l|l|}
\hline Bunn & 2000 & ARIMA, Kalman filter \\
\hline $\begin{array}{l}\text { Nogales-Contreras-Conejo- } \\
\text { Espinola }\end{array}$ & 2002 & Time series models \\
\hline $\begin{array}{l}\text { Alcalde-Ventosa-Rivier-Ramos- } \\
\text { Relano }\end{array}$ & 2002 & $\begin{array}{l}\text { Cournot based market } \\
\text { models }\end{array}$ \\
\hline Shahidehpour-Yamin-Li & 2002 & ANN \\
\hline $\begin{array}{l}\text { Contreas-Espinola-Nogales- } \\
\text { Conejo }\end{array}$ & 2003 & ARIMA \\
\hline
\end{tabular}




\begin{tabular}{|l|l|l|} 
Weron & 2006 & ARMA \\
\hline Amjady-Hemmati & 2006 & AR-ARIMA-GARCH \\
\hline Garcia-Martos-Rodrigues-Sanches & 2007 & Hybrid ARIMA \\
\hline Swider-Weber & 2007 & Extended ARMA \\
\hline Haghi-Tafreshi & 2007 & HiddenMarkov Model \\
\hline Aggarwal-Saini-Kumar & 2009 & Artificial neural network \\
\hline Mandal-Srivastava-Park & 2009 & ANN \\
\hline Niu-Liu-Wu & 2010 & Neural Network \\
\hline Areekul-Senjyu-Toyama-Yona & 2010 & $\begin{array}{l}\text { Hybrid ARIMA, Neural } \\
\text { Network }\end{array}$ \\
\hline Bordignon-Bunn-Lisi-Nan & 2011 & ARMAX \\
\hline Garcia-Martos-Rodrigues-Sanches & 2011 & VARIMA \\
\hline Inglesi-Lotz & 2011 & Kalman Filter \\
\hline $\begin{array}{l}\text { Shafie-khak-Moghaddam-El- } \\
\text { eslami }\end{array}$ & 2011 & Hybrit Neural Network \\
\hline Anbazhagan-Kumarappan & 2012 & Neural Network \\
\hline Zhang-Tang-Yang & 2012 & ARIMA, LSSVN, PSO \\
\hline Carmona-Coulon-Schwarz & 2012 & Cointegration \\
\hline Pousinho-Mendes-Catalao & 2012 & Hybrid PSO-ANFIS \\
\hline Amjady & 2012 & Neural Network \\
\hline Yan-Chowdhury & 2013 & Hybrid LSSVN, ARMAX \\
\hline Hong & 2014 & ARIMA, ANN \\
\hline Nogales & & Time series models \\
\hline Vilar-Cao-Aneiros & Seasonal ARIMA \\
\hline Source: Compiled by theauthors &
\end{tabular}

Source: Compiled by the authors

\section{Literature}

The determination of energy prices is an issue that arises from the increasing demand for energy with the industrial revolution. In time, the determination of the energy price has been associated with the determination of energy supply and demand. In addition, changes in the daily and seasonal demand for energy have gained importance in determining the energy price. This importance is mainly due to the inability to store energy. Today (2019), the development of the possibilities of storing energy and technologies, and in parallel, the increase of the utilization and capacity of alternative sustainable energy resources have brought new dimensions to energy and electricity pricing. In this context, many different methods have been used in the determination of energy prices in the literature. These methods in the literature and their results can be briefly summarized as follows.

-Bunn (2000) used innovative methods to estimate daily loads and prices in energy markets. While multiple models, combinations and neural networks have been used in demand estimations, strategic simulation models with artificial agents have been used for supply estimations. The supply estimation is a recent practice in the literature and has not yet been fully matured.

-According to Garcia et al., (2002), after 1990, the changing electricity industry worldwide has gone through restructuring for deregulation and competition. In terms of modeling simultaneous production features in this market, the Cournot balance is one of the most common theoretical frameworks for modeling market behavior. However, this model shows weakness due to its high sensitivity to demand flexibility. In this study, procedures for 
solving this problem have been shown. Moreover, the method designed for long-term business models influences the implicit values associated with the increasing demand of companies using only public market information.

-Contreras et al., (2003), in their study, estimated the end of day price of electricity by ARIMA method. While calculations for Spain and California required 5 hours for hourly price estimation, for California, this time was calculated to be 2 hours. The errors for variables were $10 \%$ in the Spanish electricity market while it was $5 \%$ in California.

-Koritarov (2004) modelled the electricity market as a complex adaptive system with an agent-based approach.

-Amjady and Hemmati (2006) focused on the problems and suggestions encountered in energy price estimation in their studies. As a result, it was stated that the data used in the calculation was very high and showed volatility over time and that the calculation methods used had deficiencies. They stated that the combination of new methods and time-series techniques to address this problem would cover the weaknesses of the models.

-Amjady (2006), in his study, tried to estimate the day-ahead price in the electricity market with a new neural network method. In the short-term price estimation in the electricity markets, it was concluded that the prices in the Spanish electricity market were determined by a dominant actor and that it had a duopolistic structure. In addition, it was concluded that the Spanish electricity markets had higher volatility compared to other markets and that the prices in this market were less predictable. It was seen that volatility and uncertainty increased more during the hours with high electricity consumption.

-Niimura (2006) focused on estimation techniques for deregulated electricity market prices. The results of electrical price estimation techniques developed after 1990 were compared. In the study, although the prediction techniques were focused on spot energy pricing, it was stated that the markets were different and therefore it was not a universal estimation tool. Therefore, it is more appropriate to select several methods according to the identified target.

-Garcia et al. (2007) estimated the short-term electricity price with the help of mixed models using 19982003 data for the Spanish market. In this framework, two separate models were formed in which weekends were included and excluded. The mean error in the estimates between 1998-2003 was calculated as $12.61 \%$. Whereas the estimation error of the model which used only working days was $11.9 \%$, the estimation error of the model where all days were used was $14.4 \%$.

-Haghi and Tafreshi (2007) compared the antistatic Markov models and the survey-based static hybrid models in energy pricing and forecasting. As a result, they grouped electricity price estimation models under three main headings. These are game theory, simulation methods, and statistical methods.

-Kumar et al. (2008) decomposed historical price data into a sub-series using a wavelet transformation in a deregulated electricity market and then combined the proposed prediction model with other time domain variables to create a set of input variables. It was observed that estimation accuracy could be improved by the use of wavelet transform in a prediction model. Finally, it was shown that a wavelet transformation based neural network model could be used to estimate the electricity price.

-Hu et al. (2009) have worked on the short-term electricity price forecast in the irregular electricity markets. By emphasizing the importance of short term electricity price estimation in their studies, they tried to determine the future trends of electricity price estimation with hybrid methods by combining different models such as Artificial Neural Network, ARIMA. As a result, it was concluded that the restructuring of energy markets created an increasing need to estimate future prices for profit maximization among market participants.

They focused on causal models used in electricity price estimation and artificial intelligence based models. While examining these models, quantitative analysis of studies, time interval for estimation, input and output variables, results, data sets used for analysis and the architecture of the model were classified. As a result, it was 
seen that the history of electricity markets was short and the price formation was very different. Developments in the calculation tools will make it easier to explain the changes in electricity prices.

-Kumar (2009b) compared the models used to estimate electricity prices, and as a result, the price estimates reported in day-ahead markets were seen to be better than those using data from real-time markets. No evidence was found for the long-term consistency of the models that were compared. However, it was seen that linear models showed better performance than nonlinear models.

-Areekul et al. (2010) made a short term price estimate with the Australian Hybrid ARIMA and Artificial Neural Network Model for the electricity market. In the study, different relational forms were tried to be captured in time series data with linear ARIMA and nonlinear Artificial Neural Network. As a result, the price correction method is recommended in new methods.

-Bent et al. (2010) examined the electricity markets within the framework of stochastic models in their books. Energy spot price dynamics, forward pricing, swap-based spot pricing were tried to be determined by stochastic models. Electricity forward transaction markets were modeled. In addition, forward and swap pricing was calculated with the Hearth-Jarrow-Morton approach. In addition to these, hedging of energy options pricing was discussed.

- Garcia et al. (2011) attempted to estimate electricity prices and volatility using unobservable components. For this purpose, a new model was used which conditionally allows removing heteroskedastic common factors from the electricity prices vector.

-Bordignon et al. (2011) attempted to combine price estimation methods for British electricity markets. Markow regime change and time-varying parameters methods were tried to be combined with simpler time series methods to predict energy prices. The results showed that combining both good operational planning and risk management yielded good results.

-Inglesi (2011) examined how the price flexibility of electricity demand in South Africa changed over time with the help of Kalman filter. It was seen that electricity prices in South Africa had a significant impact on electricity consumption due to the continuous price increases by the energy company. In the study, it was shown that energy price flexibility was an argument that changed according to time.

-Amjady (2012) stated that the time series of variables used in determining electricity price exhibited irregular movements. He stated that it was necessary to create a qualified data that included the lowest possible price factors to predict the future behavior of these movements. To this end, he proposed the use of data mining techniques and theoretical knowledge criteria.

-Chan et al. (2012) stated that smart grid systems can be produced, transmitted and consumed more efficiently and reliably than conventional electrical systems. In order to reduce the highest electrical load of smart grids, it was emphasized how to manage the demand response mechanism and how to make future investments. An effective demand response mechanism depends on price, load and renewable energy estimation.

-Bordignon et al. (2013) examined the effects of the combining of old and new models on energy price estimation. Consequently, if the combined models in ex-post comparisons performed better than individual estimates, very few of the predictions were significant. It was also found that the combined models reduced the risk of estimation.

-Yan and Chowdhury (2013) used the hybrid LSSVM (Least squares support vector machine) and ARMAX (Autoregressive moving average with external variable) approach in estimating the mid-term electricity market cleaning price.

-Carmona and Coulon (2014) conducted a study on spot prices in electricity markets. In this study, they tried to calculate forward prices by combining demand, capacity and fuel prices in various ways. In these calculations, it was aimed to prepare an infrastructure that could see the effects of renewable energy, increase in storage capacity of energy and increase of smart electric vehicles on energy prices. 
- In his study, Hong (2014) grouped the lessons learned in the long run since starting to use electrical energy under three main headings. Although low errors were calculated in energy calculations in the first place, the result was that the calculations failed. This was due to the inadequate data sets and the econometric methods used. Secondly, long-term load estimation methodology was not available due to the complexity of the models. Finally, the electricity price was driven only by the load, and the renewable wind and solar power plants affected the production and price significantly.

\section{Nash-Cournout Method}

The adequate and efficient energy supply has a critical importance for the steady growth of the economies. Many energy sectors around the world switched to the competitive markets from the command and control industry in the post-1980s. The biggest obstacle to successful reform is the regional market power. In order to solve this problem, many markets follow the multiple-settlement approach in which futures, day-ahead transactions, and realtime transactions are executed in order at different prices.

There are two approaches to the Nash-Cournot model. The strategic variables for spot energy (especially electricity) markets are assumed to be the import/export and local price premiums. The model concerns the spot and forward markets as a two-stage Nash-Cournot game that explains the demand uncertainty, flow congestion, and system prospects. The model considers the sub-game as the perfect Nash equilibrium and it solves each company with a stochastic program (Yao,2006: 1). The import/export is the strategic variable of the independent system operator in the first approach of the Nash-Cournot model. In the second approach, the companies wait for the prices determined by the independent system operator. Both approaches lead to formulations of the mixed linear descriptive problem under linear demand and marginal cost functions.

Considering the energy consumption forecasting models in terms of time and competition is important to choose which model to use on which market and conditions before using the Nash-Cournot model. The structure of the market and the period for which the forecasting is made is important to determine the model to be used for the calculations in the energy prices forecasting. The classification of this issue in the literature is as follows.

Figure 2: Theoretical market models in the context of competition and duration

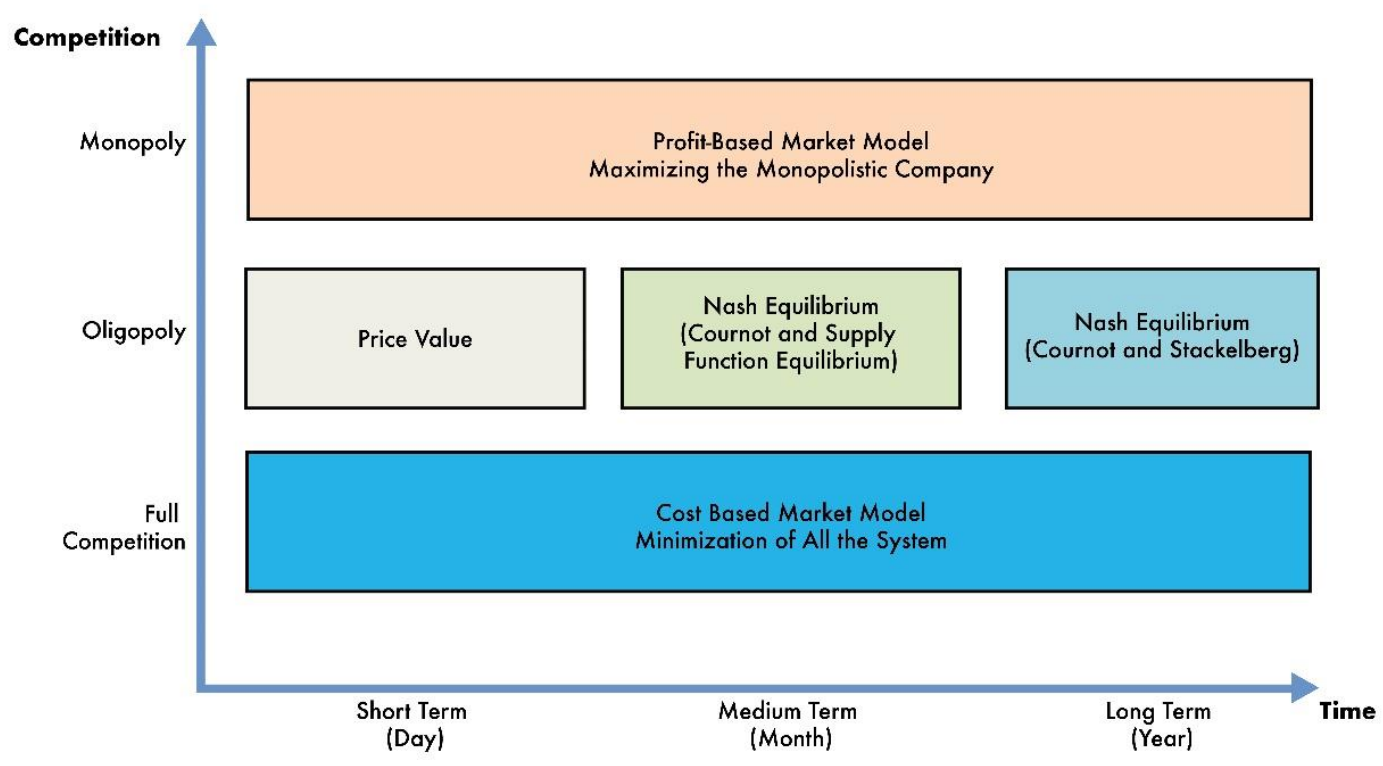

Source: Ventosa et.al., 2005:906

The Nash-Cournot model is an appropriate model for the determination of the spot market price in oligopoly markets. There are four different situations in this framework. These are called as the first spot market model, the 
second spot market model, the first two settlement models and the second two settlement models in the literature. In the first spot market model, each company uses $g \in G N_{g}$ to determine output quantity $\left(\left\{q_{i}\right\}_{i \in N g}\right)$. These quantities should not be negative and should not exceed the corresponding upper capacity limits $\left(\{\bar{q}\}_{i \in N g}\right)$.

$$
0 \leq q_{i} \leq \bar{q}_{i}, i \in N_{g},
$$

The first approach suggests that the energy and transmission markets are cleaned in turn and that the production companies' production decisions predict the effects on the transmission prices determined by the independent system operators. It leads to a multi-leader single follower Stackelberg game in the spot market. Each manufacturer solves the resulting equilibrium by using the following parametric mathematical pattern in accordance with the constraints imposed by the independent system operator.

$$
\max _{q_{i} i: i \in N g} \sum_{i \in N g} P_{i}\left(r_{i}+q_{i}\right) q_{i}-\sum_{i \in N g} C_{i}\left(q_{i}\right)
$$

The above problem is referred to as "Generalized Nash Game". The problem may either have no solution or multiple solutions. Moreover, even if a solution is found, it is usually degenerate. In other words, companies can lead to congestion on certain transmission lines to avoid congestion rental costs. Moreover, it is quite difficult to calculate the equilibrium by using this formulation in a real-size grid (Yao, 2006 18-19).

Unlike the node export/import in the first model, the second spot market model assumes the strategic variables of the independent system operator as local price premiums. While each company estimates the production and the price premiums of its competitors by using the aggregate demand function, they determine their own production by using the reference model to determine the energy price. The model solves the profit maximization problem by using the following function.

$$
\max _{q_{i}: i \in N g, P} \sum_{i \in N g} P_{i}\left(P+\vartheta_{i}\right) q_{i}-\sum_{i \in N g} C_{i}\left(q_{i}\right)
$$

The second spot market model overcomes the shortcomings of the first model. Since the resource ownership structure is taken into account and grid constraints are eased, regional price premiums become zero. Thus, the model produces the same equilibrium solution as the Cournot balance applied to the total system demand. However, a lack of the model arises when the capacity of the energy transmission lines is reset or the radial line is constantly congested. For example, in the case of a single-line grid with symmetric nodes, decreasing the line capacity to zero creates two local monopolies.

The first two settlement models are used to calculate the oligopolistic equilibrium in a given grid. As a twoway Nash-Cournot game with full information, the two companies are considered to be a forward market in the period of zero and a spot market in the period of one. The energy companies determine forward commitments by forecasting future orders of each other and spot market results in order to maximize their order in the forward markets. The spot market is a two-stage sub-game. The conformance of the natural conditions is the determinant factor at the first stage. In the second stage, the companies make adjustments to maximize their total profits by defining their own conditions. The figure below shows the dynamics of the perfect Nash equilibrium. 


\section{International Journal of Business and Applied Social Science}

EISSN: 2469-6501

VOL: 5, ISSUE:7

JULY/2019

DOI: 10.33642/ijbass.v5n7p1

https://ijbassnet.com/

(c) Center for Promoting Education and Research

WWW.cpernet.org

Figure 3: Model Dynamics

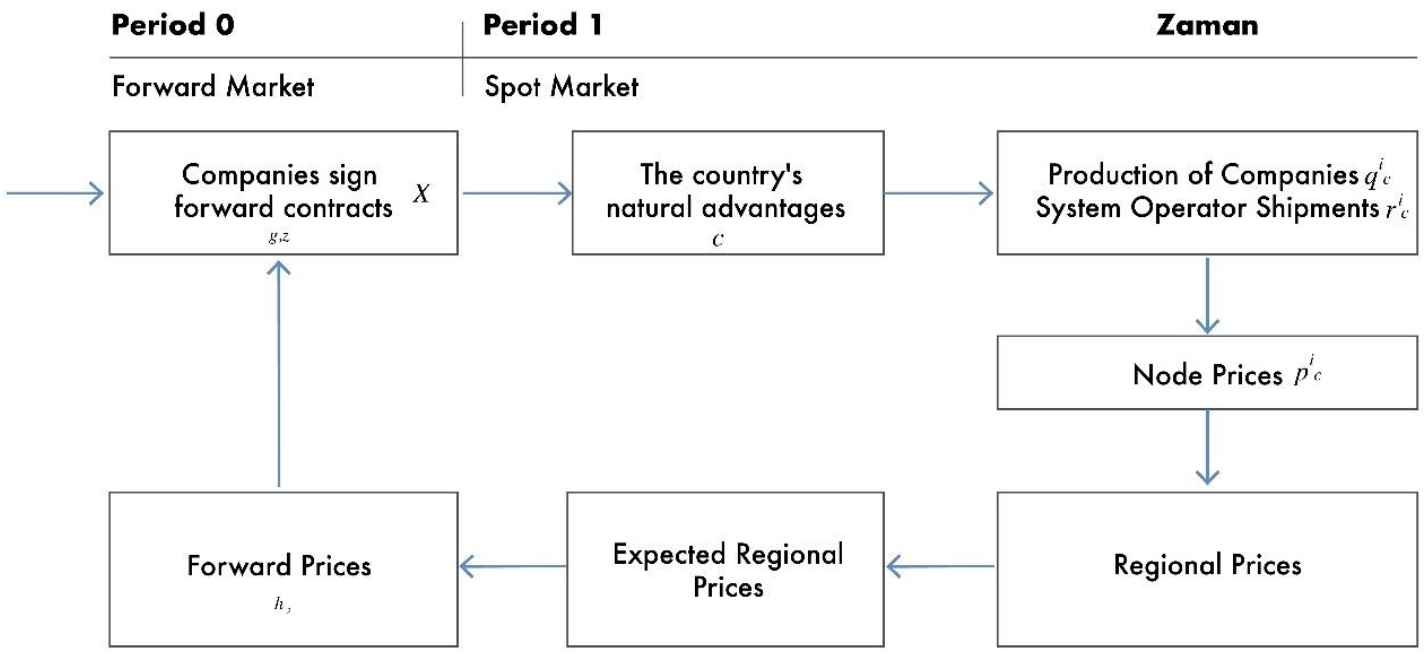

Source: Yao, 2006: 42

The model is presented as a mathematical equilibrium model. The model consists of a set of mathematical programs with an equilibrium-constrained equilibrium problem. The equilibrium constraints characterize the decisions of the individually acting companies. Each mathematical equilibrium constraint consists of the equilibrium conditions of the lower-level companies in the spot market and higher-level companies in the forward market.

Finally, the second two-settlement model expands the second spot market model to two-settlement model. The current model is regarded as a two-player two-period Nash-Cournot game for the spot and forward markets. In this model, the Cournot balance is presented as an equilibrium problem with the equilibrium constraints. The spot market balance in the model seeks solutions to combined optimized conditions for the programs of both the companies and the independent system operator. However, the strategic variables of the independent system operator are assumed to be built-in price premiums.

\section{The Energy Prices And Their Forecasting In Turkey}

As of 2016 in Turkey, $32.1 \%$ of the electricity has been produced from natural gas, 39.9\% from the coal, $24.7 \%$ from the hydroelectricity, $5.7 \%$ from the wind energy, $1.8 \%$ from the geothermal energy, and $1.8 \%$ from the other sources. The number of power plants in Turkey is 2321 as of the end of 2016. 597 of them are hydroelectric power plants, 39 are coal power plants, 171 are wind power plants, 31 are geothermal power plants, 260 are natural gas power plants, 1045 are solar power plants, and 178 are other power plants (Republic of Turkey Ministry of Energy and Natural Resources, 2016).

As of 2016, the number of companies operating in the energy sector in Turkey is 289.267 of these companies actively produce energy (Table 3). The number of companies producing energy has increased in the post2000 period. In addition to the companies that produce only energy, the holdings and large companies have invested in energy to meet their needs.

Table 3: Power Production Companies in Turkey-1

\begin{tabular}{|c|c|c|c|}
\hline 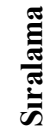 & Firma & $\begin{array}{c}\text { Santral } \\
\text { Sayısı }\end{array}$ & $\begin{array}{c}\text { Kurulu } \\
\text { Güicü }\end{array}$ \\
\hline 2) & Enka Enerji Elektrik Üretim & 3 & 3.830 \\
\hline 3) & Enerjisa Enerji Üretim A.Ş. & 21 & 3.694 \\
\hline 4) & Eren Holding Enerji Grubu & 4 & 2.927 \\
\hline
\end{tabular}




\begin{tabular}{|c|c|c|c|}
\hline 5) & Limak Enerji A.Ş. & 10 & 2.218 \\
\hline 6) & Aksa Enerji A.Ş. & 12 & 1.956 \\
\hline 11) & Konya Şeker Enerji & 5 & 1.525 \\
\hline 12) & Çelikler Holding Enerji Grubu & 9 & 1.324 \\
\hline 13) & Diler Holding Enerji Grubu & 2 & 1.238 \\
\hline 14) & Akenerji & 9 & 1.221 \\
\hline 15) & Gama Enerji A.Ş. & 9 & 1.088 \\
\hline 16) & Ciner Enerji Grubu & 3 & $988 \mathrm{MW}$ \\
\hline 20) & Bilgin Enerji Yatırım Holding A.Ş. & 11 & $690 \mathrm{MW}$ \\
\hline 21) & Sanko Enerji Sanayi ve Ticaret A.Ş. & 9 & $685 \mathrm{MW}$ \\
\hline 22) & Zorlu Enerji Grubu & 16 & $644 \mathrm{MW}$ \\
\hline 24) & Çolakoğlu Metalurji Enerji Grubu & 3 & $567 \mathrm{MW}$ \\
\hline 28) & Kolin İnşaat Enerji Grubu & 9 & $513 \mathrm{MW}$ \\
\hline 32) & Borusan EnBW Enerji & 10 & $399 \mathrm{MW}$ \\
\hline 33) & Demirer Holding Enerji Grubu & 17 & $395 \mathrm{MW}$ \\
\hline 35$)$ & İzmir Demir Çelik İzdemir Enerji & 1 & $350 \mathrm{MW}$ \\
\hline 40) & Eksim Yatırım Holding Enerji Grubu & 7 & $308 \mathrm{MW}$ \\
\hline 42) & Habaş Sınai ve Tibbi Gazlar & 3 & $294 \mathrm{MW}$ \\
\hline 43) & Şişecam Topluluğu & 2 & $285 \mathrm{MW}$ \\
\hline 46) & Altek Alarko Enerji Elektrik Santralleri A.Ş. & 3 & $252 \mathrm{MW}$ \\
\hline 47) & Boydak Enerji Üretim ve Ticaret A.Ş. & 12 & $246 \mathrm{MW}$ \\
\hline 52$)$ & Gülsan Holding Enerji Grubu & 5 & $230 \mathrm{MW}$ \\
\hline 54) & Akfen Holding Enerji Grubu & 14 & $219 \mathrm{MW}$ \\
\hline 55) & Koç Holding & 5 & $219 \mathrm{MW}$ \\
\hline 56) & Karadeniz Holding Enerji Grubu & 4 & $205 \mathrm{MW}$ \\
\hline 57) & Naksan Plastik ve Enerji Sa. ve Tic. A.Ş. & 4 & $193 \mathrm{MW}$ \\
\hline 58) & Türkiye Şeker Fabrikaları A.Ş. & 23 & $187 \mathrm{MW}$ \\
\hline 59) & Kalyon İnşaat Enerji Grubu & 5 & $173 \mathrm{MW}$ \\
\hline 60) & Türkerler Holding Enerji Grubu & 6 & $171 \mathrm{MW}$ \\
\hline 66) & Alto Holding Enerji Grubu & 2 & $144 \mathrm{MW}$ \\
\hline 69) & Aksa Akrilik Kimya Sanayii A.Ş. & 1 & $143 \mathrm{MW}$ \\
\hline 70) & Manisa Organize Sanayi Bölgesi Enerji Elektrik Üretim & 1 & $140 \mathrm{MW}$ \\
\hline 78) & Ünal Şirketler Grubu & 3 & $112 \mathrm{MW}$ \\
\hline 79) & Arsan Group & 7 & $110 \mathrm{MW}$ \\
\hline 81$)$ & Zafer Şirketler Grubu & 3 & $104 \mathrm{MW}$ \\
\hline 83) & Kardemir Demir Çelik Fabrikaları & 2 & $99 \mathrm{MW}$ \\
\hline 84) & MÖN İnşaat Enerji Grubu & 3 & $99 \mathrm{MW}$ \\
\hline 86) & Ece Tur Şirketler Grubu & 2 & $94 \mathrm{MW}$ \\
\hline 89) & Rönesans Holding Enerji Grubu & 5 & $92 \mathrm{MW}$ \\
\hline 90) & Çalık Enerji & 3 & $92 \mathrm{MW}$ \\
\hline 91) & Melike Group Melike Tekstil & 5 & $90 \mathrm{MW}$ \\
\hline 96) & Y1lsan Yatırım Holding Enerji Grubu & 5 & $80 \mathrm{MW}$ \\
\hline 97) & Küçükler Holding A.Ş. & 9 & $78 \mathrm{MW}$ \\
\hline
\end{tabular}

Table 4: Power Production Companies in Turkey-2

\begin{tabular}{|c|c|c|c|}
\hline 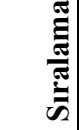 & Firma & $\begin{array}{c}\text { Santral } \\
\text { Sayısı }\end{array}$ & $\begin{array}{c}\text { Kurulu } \\
\text { Gücüi }\end{array}$ \\
\hline 100) & Yüksel Holding Enerji Grubu & 1 & $74 \mathrm{MW}$ \\
\hline 102) & Aksu Grup & 3 & $73 \mathrm{MW}$ \\
\hline 103) & Sancak Holding Enerji Grubu & 3 & $70 \mathrm{MW}$ \\
\hline 104) & MB Holding Enerji Grubu & 4 & $68 \mathrm{MW}$ \\
\hline 105) & Erdem Holding & 2 & $66 \mathrm{MW}$ \\
\hline 108) & GSD Holding Enerji Grubu & 1 & $61 \mathrm{MW}$ \\
\hline 116) & Erciyas Holding Enerji Grubu & 1 & $50 \mathrm{MW}$ \\
\hline 120) & Tekno Şirketler Grubu & 4 & $48 \mathrm{MW}$ \\
\hline
\end{tabular}




\begin{tabular}{|c|c|c|c|}
\hline 121) & Kibar Holding Enerji Grubu & 1 & $48 \mathrm{MW}$ \\
\hline 126) & Akbaş Holding Enerji Grubu & 2 & $45 \mathrm{MW}$ \\
\hline 131) & Marmara Pamuklu Mensucat & 1 & $44 \mathrm{MW}$ \\
\hline 136) & Nurol Enerji Üretim ve Pazarlama A.Ş. & 2 & $42 \mathrm{MW}$ \\
\hline 138) & Boyut Grup Enerji Ltd. Şti. & 4 & $39 \mathrm{MW}$ \\
\hline 143) & BM Holding & 3 & $38 \mathrm{MW}$ \\
\hline 144) & Bilkent Holding Enerji Grubu & 1 & $37 \mathrm{MW}$ \\
\hline 146) & Hayat Kimya Sanayi A.Ş. & 1 & $35 \mathrm{MW}$ \\
\hline 147) & Kardemir Haddecilik ve Elektrik Üretim LTD. ŞTİ. & 2 & $35 \mathrm{MW}$ \\
\hline 148) & Koçoğlu İnşaat Enerji Grubu & 3 & $34 \mathrm{MW}$ \\
\hline 149) & Adalı Holding Enerji Grubu & 2 & $33 \mathrm{MW}$ \\
\hline 150) & Kayseri Şeker Fabrikası & 3 & $33 \mathrm{MW}$ \\
\hline 155) & Akkanat Holding Enerji Grubu & 1 & $28 \mathrm{MW}$ \\
\hline 160) & Şahinler Holding Enerji Grubu & 1 & $26 \mathrm{MW}$ \\
\hline 163) & Kastamonu Entegre Ağaç San. ve Tic. A.Ş. & 1 & $26 \mathrm{MW}$ \\
\hline 169) & TAV Havalimanları Holding A.Ş. & 3 & $23 \mathrm{MW}$ \\
\hline 170) & Bükköy Madencilik Turizm İnşaat Elektrik Üretim A.Ş. & 1 & $23 \mathrm{MW}$ \\
\hline 171) & MMK Metalurji A.Ş. & 2 & $23 \mathrm{MW}$ \\
\hline 172) & Yildız Sunta MDF & 1 & $23 \mathrm{MW}$ \\
\hline 177) & Bayraktar İnşaat Enerji Grubu & 2 & $21 \mathrm{MW}$ \\
\hline 181) & Ortadoğu Rulman Sanayi & 1 & $20 \mathrm{MW}$ \\
\hline 184) & As-Ka Grup Enerka Enerji & 1 & $19 \mathrm{MW}$ \\
\hline 185) & Ati İnşaat Enerji & 1 & $19 \mathrm{MW}$ \\
\hline 193) & ÖDF Yılmazlar İnşaat Enerji Grubu & 1 & $18 \mathrm{MW}$ \\
\hline 200) & Tekfen Holding A.Ş. & 2 & $17 \mathrm{MW}$ \\
\hline 204) & Okan Holding Enerji Grubu & 2 & $16 \mathrm{MW}$ \\
\hline 214) & Tırsan Enerji Elektrik Üretim A.Ş. & 1 & $12 \mathrm{MW}$ \\
\hline 223) & Sakarya Büyükşehir Belediyesi & 1 & $9,60 \mathrm{MW}$ \\
\hline 229) & Aytemiz Petrol A.Ş. & 1 & $8,78 \mathrm{MW}$ \\
\hline 235) & Amasya Şeker Fabrikası A.Ş. & 1 & $7,76 \mathrm{MW}$ \\
\hline 247) & Asunim Group & 1 & $6,00 \mathrm{MW}$ \\
\hline 248) & Usluel Grup & 1 & $5,80 \mathrm{MW}$ \\
\hline 249) & Humartaş Yapı ve Enerji A.Ş. & 1 & $5,77 \mathrm{MW}$ \\
\hline 255) & Portsan Şirketler Grubu & 2 & $4,86 \mathrm{MW}$ \\
\hline 257) & Afyon Enerji ve Gübre Üretim & 1 & $4,02 \mathrm{MW}$ \\
\hline 258) & Mustafa Modoğlu Holding Enerji Grubu & 2 & $3,83 \mathrm{MW}$ \\
\hline 265) & Masfen İnşaat Enerji San. Tic. A.Ş. & 1 & $0,96 \mathrm{MW}$ \\
\hline 267) & Abalıoğlu Holding Enerji Grubu & 1 & $0,46 \mathrm{MW}$ \\
\hline
\end{tabular}

Source: Energy Atlas, 2016

The growing market has also impact on the increase in the interest in the energy sector. It is predicted that the energy sector, which is about 55 billion USD as of 2015, will grow even larger in the future. The increasing competition in the sector is another issue that makes forecasting energy prices important in the future.

For the calculations made within the framework of the approach examined in the study, one-week samples have been used to forecast the day ahead market reference price. Two main approaches have been used to forecasting day ahead reference price, namely models based on simulation and mathematical models. It has been seen that the market exchange price and the average prices increase in the unit price of $\mathrm{KW} / \mathrm{h}$ in the calculations made based on the data of EPİAŞ for the period of 2003-2016. While the marginal price was $18.5 \mathrm{kurus} / \mathrm{kWh}$ and the average price was $12.8 \mathrm{kurus} / \mathrm{kWh}$ in 2013 , these figures are calculated as $29.1 \mathrm{kurus} / \mathrm{kWh}$ and $20.1 \mathrm{kurus} / \mathrm{kWh}$ in 2017, respectively.

Considering the relationship between the market clearing price and the system marginal price, the energy deficit and energy surplus can be determined. If the system marginal price is greater than the market clearing price, it is interpreted as an energy deficit. Otherwise, it is interpreted as an energy surplus. The system marginal price has been calculated greater than the market clearing price in the calculations for the overall average for 2017 in Turkey. So, there is an energy deficit. More clearly, the average energy demand in the day is above the energy supply. This difference appears to have been increased between 2013 and 2017. While the difference was $5.7 \mathrm{kurus} / \mathrm{kWh}$ in 2013 
it has become 9 kurus/kWh in 2017. It can be easily seen that this difference will increase even more in the near future from the following table which shows the increase in energy demand.

Table 5: Energy Demand Forecast 2015-2024

\begin{tabular}{|c|c|c|c|c|}
\hline \multirow{2}{*}{ Yıl } & \multicolumn{2}{|c|}{ Puant Demand } & \multicolumn{2}{c|}{ Energy Demand } \\
\cline { 2 - 5 } & $\mathbf{M V}$ & Increase \% & GWh & Increase \% \\
\hline 2015 & 41402 & 1,0 & 268820 & 4,5 \\
\hline 2016 & 43826 & 5,9 & 284540 & 5,9 \\
\hline 2017 & 46383 & 5,8 & 301160 & 5,8 \\
\hline 2018 & 49043 & 5,7 & 318430 & 5,7 \\
\hline 2019 & 51861 & 5,7 & 336730 & 5,7 \\
\hline 2020 & 54811 & 5,7 & 358880 & 5,7 \\
\hline 2021 & 57689 & 5,3 & 374570 & 5,3 \\
\hline 2022 & 60668 & 5,2 & 393910 & 5,2 \\
\hline 2023 & 63759 & 5,1 & 413980 & 5,1 \\
\hline 2024 & 66998 & 5,1 & 435010 & 5,1 \\
\hline
\end{tabular}

Source: Turkish Power Transmission, 2015

\section{IN LIEU OF CONCLUSION}

Although Nash-Cournot models are popular, they are not realistic methods for modeling strategic interactions in energy markets. However, the models proposed in this study can calculate the incomplete competitive equilibrium for the grids with hundreds or even thousands of control areas or data paths

Although the Nash-Cournot method has some incomplete aspects, the results obtained are similar to those obtained by using different methods. We can classify the obtained results for the users as follows. The industrial companies in Turkey want to know the future cost of the energy they use. On the other hand, the companies in the energy sector want to predict changes in the input costs. The companies in the energy sector also want to forecast the future energy demand and the fluctuations in the unit prices of the energy. In this framework, these forecasts become more important especially for Turkey which is dependent on energy import. The dependence on foreign sources (such as oil, natural gas, coal) used to generate energy is one of the biggest uncertainties in terms of energy producing companies. Moreover, energy prices are also important for the international competitiveness of the companies exporting energy. Besides predicting the future prices of energy in Turkey, efforts made to reduce the unit cost of energy are also important.

\section{References}

Areekul, Phatchakorn, Tomonobu Senjyu, Hirofumi Toyama, ve Atsushi Yona, (2010), "A Hybrid ARIMA and Neural Network Model for Short-Term Price Forecasting in Deregulated Market", IEEE Transactıons On Power Systems, Vol. 25, No. 1, February, ss.524-530.

Amjady, Nima, (2006), "Day-Ahead Price Forecasting of Electricity Markets by a New Fuzzy Neural Network", IEEE Transactions On Power Systems, Vol. 21, No. 2, May.

Amjady, Nima ve Meisam Hemmati (2006) "Energy Price Forecasting Problems And Proposals For Such Predictions", IEEE Power \& Energy Magazine, March/April, ss.20-29.

Amjady, Nima, (2012), “Short-Term Electricity Price Forecasting”, Electric Power Systems, João P. S. Catalão (Edt), CRC Press, ss.4.1-4.58.

Benth Fred Espen, Jurate Saltyte Benth ve Steen Koekebakker (2010), Stochastic Modelling of Electricity and Related Markets, World Scientific Publishing Co. Pte. Ltd. 
Bordignon, Silvano, Derek W. Bunn, Francesco Lisi ve Fany Nan (2011), "Combining Forecasts For Electricity Prices", Department of Statistical Sciences, University of Padua, Working Paper Series, N. 1, January, ss. 1-26.

Bordignon, Silvano, Derek W. Bunn, Francesco Lisi ve Fany Nan (2013), "Combining Day-Ahead Forecasts For British Electricity Prices", Energy Economics, 35 (2013) 88-103.

Bunn, Derek W. (2000), "Forecasting Loads and Prices in Competitive Power Markets", Proceedings of The IEEE, VOL. 88, NO. 2, February, 163-169.

Business INSIDER (2016), The 15 "Biggest Energy Companies in the World", http://www. businessinsider.com/the-15-biggest-energy-comapnies-in-the-world-2011-10\#endesa-sa-1,(Erişimtarihi: 10.03.2017).

Carmona, Rene ve Michael Coulon (2014), "A Survey of Commodity Markets and Structural Models for Electricity Prices", F.E. Benth (eds.), Quantitative Energy Finance: Modeling, Pricing, and Hedging in Energy and Commodity Markets, 41-83.

Cerjan, Marin, Ivana Krzelj, Marko Vidak, Marko Delimar (2013), "A Literature Review with Statistical Analysis of Electricity Price Forecasting Methods", EuroCon 2013 1-4 July, 756-763

Chan, S.C., K.M. Tsui, H.C. Wu, Yunhe Hou, Yik-Chung Wu, ve Felix F. Wu (2012), "Load/Price Forecasting and Managing Demand Response for Smart Grid”, IEEE Signal Processing Magazine, September, 68-85.

Contreras, Javier, Rosario Espínola, Francisco J. Nogales, ve Antonio J. Conejo (2003), “ARIMA Models to Predict Next-Day Electricity Prices”, IEEE Transactions On Power Systems, Vol. 18, No. 3, August, 1014-1020.

Daneshi, Hossein, A. Daneshi (2008), "Price Forecasting in Deregulated Electricity Markets - A Bibliographical Survey", DRPT2008, 1-5.

Enerji Atlasi (2016), Elektrik Üretim Firmaları, www.enerjiatlası.com/firma/, (Erişim tarihi: 17.03.2017).

García-Alcalde, Antonio, Mariano Ventosa, Michel Rivier, Andrés Ramos ve Gregorio Relaño (2002), "Fittıng Electricity Market Models. A Conjectural Variations Approach”, 14th PSCC, Sevilla 24-28 June.

Garcia-Martos, Carolina, Julio Rodriguez-Maria Jesus Sanches (2007), "Mixed Models for Short-Run Forecasting of Electricity Prices: Application for the Spanish Market", IEEE Transactions on Power Systems, Volume: 22, Issue: 2, 544-552.

Garcia-Martos, Carolina, Julio Rodriguez-Maria Jesus Sanches (2011), "Forecasting Electricity Prices and Their Volatilities Using Unobserved Components", Energy Economics, Volume 33, Issue 6, November 2011, Pages 1227-1239.

Hagh1, Hamed Valizadeh, ve S. M. Moghaddas Tafreshi (2007), "Modeling and Forecasting of Energy Prices using Non-stationary Markov Models versus Stationary Hybrid Models including a Survey of all Methods", IEEE Canada Electrical Power Conference, 429-434.

Hong, Tao (2014), "Energy Forecasting: Past, Present and Future", The International Journal of Applied Forecasting, (32), 43-48.

Hu, Lin, Gareth Taylor, Hai-Bin Wan ve Malcolm Irving, (2009), "A Review of Short-Term Electricity Price Forecasting Techniques in Deregulated Electricity Markets", IEEE Xplore,

Ingles1-Lotz, Roula, (2011), "The Evolution of Price Elasticity of Electricity Demand in South Africa : A Kalman Filter Application", Energy Policy, 39, 3690-3696.

Korttarov, Vladimir S. (2004), "Real-World Market Representation with Agents", IEEE Power \& Energy Magazine, 39-46. 
Kumar, Sanjeev Aggarwal, Lalit Mohan Saini, ve Ashwani Kumar (2008), "Electricity Price Forecasting in Ontario Electricity Market Using Wavelet Transform in Artificial Neural Network Based Model", International Journal of Control, Automation, and Systems, vol. 6, no. 5, pp. 639-650.

Kumar, Sanjeev Aggarwal, Lalit Mohan Saini, ve Ashwani Kumar (2009a), "Electricity price forecasting in deregulated markets: A review and evaluation", Electrical Power and Energy Systems 31 (2009) 13-22.

Kumar, Sanjeev Aggarwal, Lalit Mohan Saini, ve Ashwani Kumar (2009b), "Short term price forecasting in deregulated electricity markets A review of statistical models and key issues", International Journal of Energy Sector Management, Vol. 3 No. 4, ss. 333-358.

Nı1mura, Takahide. (2006), "Forecasting Techniques for Deregulated Electricity Market Prices - Extended Survey", IEEE PES Power Systems Conference and Exposition, 51-56.

T.C. Enerji Ve Tabii Kaynaklar Bakanliği (2016), Elektrik, http://www.enerji.gov.tr/ tr-TR/Sayfalar/Elektrik. (Erişim tarihi:15.03.2017).

Türkiye Elektrik İletim A.Ş (2015), Türkiye Elektrik Enerjisi 5 Yıllık Üretim Kapasite Projeksiyonu (2015-2019), Türkiye Elektrik İletim A.Ş. Genel Müdürlüğü Planlama ve Stratejk Yönetim Dairesi Başkanlığı, 1-96.

Ventosa, Mariano, Alvaro Baillo, Andres Ramos, Michel Rivier (2005), "Electricity Market Modeling Trends", Energy Policy 33, 897-913

Vlachogianni, Thomais, AthanasiosValavanidis (2013), "Energy and Environmental Impact on the Biosphere Energy Flow, Storage and Conversion in Human Civilization", American Journal of Educational Research, Vol. 1, No. 3, 68-78.

Yan, Xing, Nurul A. Chowdhury (2013), "Mid-Term Electricity Market Clearing Price Forecasting: A Hybrid LSSVM And ARMAX Approach", Electrical Power and Energy Systems, 53, 20-26.

Yao, Jian (2006), Cournot Equilibrium in Two-settlement Electricity Markets: Formulation and Computation, Yayınlanmamış doktora tezi, University of California, Berkeley, 1-121. 